\title{
0734. Early changes in heart rate predict long-term survival in a rodent model of sepsis
}

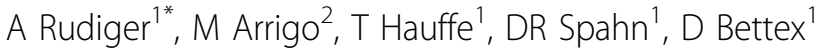 \\ From ESICM LIVES 2014 \\ Barcelona, Spain. 27 September - 1 October 2014
}

\section{Introduction}

In sepsis, early prognostication of outcome would be helpful both for the detection of underlying mechanisms (adaptive vs. maladaptive) and the development of novel treatments for potential non-survivors.

\section{Objectives}

We tested whether telemetry derived heart rate (HR) changes during early sepsis could prognosticate outcome in a long-term rat model of fecal peritonitis.

\section{Methods}

Male Wistar rats were instrumented with telemetry for continuous HR and temperature recording. Abdominal sepsis was induced by intraperitoneal injection of fecal slurry. A jugular catheter allowed the intravenous administration of opioids (nalbuphin $1 \mathrm{mg} / \mathrm{kg} / \mathrm{h}$ ), antibiotics (rocephin $30 \mathrm{mg} / \mathrm{kg}$ at 4 and $24 \mathrm{~h}$ ) and crystalloids (bolus of $20 \mathrm{ml} / \mathrm{kg}$ at $4 \mathrm{~h}$, followed by an infusion of $10 \mathrm{ml} / \mathrm{kg} / \mathrm{h}$, halved after 8 and 24h). The awake animals were followed for 48 hours.

\section{Results}

Septic animals became lethargic and febrile. Mortality was $30 \%$, and all deaths occurred between 4 and 24 hours. Postmortem examination showed variable degrees of peritonitis and purulent ascites. Rats surviving 24 hours showed clinical signs of recovery.

ROC analysis revealed that the change in HR between baseline and $4 \mathrm{~h}$ was a good prognosticator (AUC 0.84, 95\% CI 0.56-1.00; $\mathrm{p}=0.03$ ). An increase in HR of $\geq 50 \mathrm{bpm}$ between baseline and 4 hours separated survivors and non-survivors with a sensitivity and specificity of $80 \%$ and $100 \%$, respectively.

${ }^{1}$ University Hospital Zurich, Institute of Anesthesiology, Zurich, Switzerland Full list of author information is available at the end of the article
Table 1 Heart rate (bpm) in survivors and non-survivors:

\begin{tabular}{llll}
\hline & Survivors $(\mathrm{n}=14)$ & Non-survivors $(\mathrm{n}=6)$ & $\mathrm{p}$-value \\
\hline At BL & $405(329-471)$ & $394(296-439)$ & 0.31 \\
\hline $\begin{array}{l}4 \mathrm{~h} \text { after septic } \\
\text { insult }\end{array}$ & $389(318-440)$ & $452(349-494)$ & 0.11 \\
\hline $\begin{array}{l}6 \text { hours post } \\
\text { septic insult }\end{array}$ & $416(331-494)$ & $500(418-594)$ & 0.02 \\
\hline $\begin{array}{l}\text { Change BL to } \\
4 \text { hours }\end{array}$ & $-10(-87-49)$ & $61(-52-85)$ & $<0.01$ \\
\hline
\end{tabular}

Values are median (range); $\mathrm{BL}=$ baseline

\section{Conclusions}

In this clinically relevant rat model of abdominal sepsis changes in HR as early as 4 hours after the septic insult predicted outcome with good sensitivity and excellent specificity. This will allow future investigation of adaptive changes in potential survivors and mechanisms of death in potential non-survivors. In addition, novel sepsistreatments (e.g. beta-blockers) can be tested in regards of their beneficial and harmful effects in potential nonsurvivors and survivors.

\section{Grant acknowledgment}

ESICM ECCRN Established Investigator Award 2011 to Alain Rudiger

\section{Authors' details}

'University Hospital Zurich, Institute of Anesthesiology, Zurich, Switzerland.

${ }^{2}$ University Hospital Zurich, Clinic for Cardiology, Zurich, Switzerland.

Published: 26 September 2014

References
1. Dyson A, Rudiger A, Singer M: Intensive Care Med 2011, 37:1192-200.
2. Rudiger A, Dyson A, Felmann K, et al: Clin Science 2013, 124:391-401.

doi:10.1186/2197-425X-2-S1-P56

Cite this article as: Rudiger et al:: 0734 . Early changes in heart rate predict long-term survival in a rodent model of sepsis. Intensive Care Medicine Experimental 2014 2(Suppl 1):P56.

\section{SpringerOpen ${ }^{\circ}$}

(C) 2014 Rudiger et al; licensee Springer. This is an Open Access article distributed under the terms of the Creative Commons Attribution License (http://creativecommons.org/licenses/by/2.0), which permits unrestricted use, distribution, and reproduction in any medium, provided the original work is properly cited. 